\title{
PENINGKATAN KINERJA GURU TERHADAP EFEKTIFITAS PEMBELAJARAN MELALUI SUPERVISI KLINIS DI SEKOLAH MENENGAH PERTAMA
}

\author{
Zainuddin \\ Kepala SMP Negeri 4 Birem Bayeun, Kec. Birem Bayeun, Kab. Aceh Timur \\ pak.alank13@gmail.com
}

\begin{abstract}
Basically the task of the teacher is to educate, teach, train and evaluate students, so that students can become human beings who can carry out life in harmony with their nature as humans. related to the teacher's task in evaluating students, the teacher should have teaching skills. For this reason the principal's role is needed to motivate teachers to improve their performance and supervision objectives to help teachers see clearly the educational goals and try to achieve those educational goals by fostering and developing better teaching methods and procedures. The purpose of this study is to improve teacher performance in order to devote time and energy to making learning effective. Improve the ability to solve problems in learning through clinical supervision. The results of the description analysis revealed that in cycle I (one) the level of teacher performance towards learning effectiveness had shown an increase compared to the initial conditions. But the results achieved in the first cycle did not make researchers feel satisfied because they are less than optimal. Therefore, researchers continued in the second cycle by first making improvements to the weaknesses contained in cycle I. In the implementation of the second cycle there was a significant increase in the effectiveness of learning. The conclusion of this study is through Clinical Supervision Can Improve Teacher Performance Against the Effectiveness of Learning at SMem 4 Birem Bayeun, East Aceh District.
\end{abstract}

Keywords: Teacher Performance, Clinical Supervision

\begin{abstract}
ABSTRAK
Pada dasarnya tugas guru mendidik, mengajar, melatih serta mengevaluasi siswa, agar peserta didik dapat menjadi manusia yang dapat melaksanakan kehidupan selaras dengan kodratnya sebagai manusia. berkaitan dengan tugas guru didalam mengevaluasi siswa maka guru hendaknya memiliki ketrampilan mengajar. Untuk itu diperlukan peran kepala sekolah untuk memotivasi para guru untuk meningkatkan kinerjanya dan tujuan supervisi untuk membantu guru-guru melihat dengan jelas tujuan pendidikan dan berusaha mencapai tujuan pendidikan itu dengan membina dan mengembangkan metode-metode dan prosedur pengajaran yang lebih baik. Tujuan dari penelitian ini adalah ingin meningkatkan kinerja guru agar dapat mencurahkan waktu dan tenaga untuk mengefektifkan pembelajaran. Meningkatkan kemampuan dalam memecahkan masalah dalam pembelajaran melalui supervisi klinis. Hasil analisis deskripsi mengungkapkan, pada siklus I (satu) tingkat kinerja guru terhadap efektifitas pembelajaran sudah menunjukkan peningkatan disbanding dengan kondisi awal. Namun hasil yang dicapai pada siklus I tidaklah menjadikan peneliti merasa puas karena kurang maksimal. Oleh karena itu peneliti melanjutkan pada siklus II dengan terlebih dahulu melakukan perbaikan atas kelemahan yang terdapat pada siklus I. Pada pelaksanaan tindakan siklus II terjadi peningkatan yang cukup signifikan terhadap efektifitas pembelajaran. Kesimpulan dari penelitian ini adalah Melalui Supervisi Klinis Dapat Meningkatkan Kinerja Guru Terhadap Efektifitas Pembelajaran Pada SMPN 4 Birem Bayeun Kabupaten Aceh Timur.
\end{abstract}

Kata Kunci: Kinerja Guru, Supervisi Klinis

\section{Author correspondence}

Email:pak.alank13@gmail.com

Available online at http://ejurnalunsam.id/index.php/jsnbl/index 
SEUNEUBOK LADA

Jurnal Ilmu-Ilmu Sejarah, Sosial, Budaya dan Kependidikan, 7 (1), 2020: 66-79

ISSN : 2356-0770

e-ISSN : 2685-2705

\section{A. PENDAHULUAN}

Pada dasarnya tugas guru mendidik, mengajar, melatih serta mengevaluasi siswa, agar peserta didik dapat menjadi manusia yang dapat melaksanakan kehidupan selaras dengan kodratnya sebagai manusia. berkaitan dengan tugas guru didalam mengevaluasi siswa maka guru hendaknya memiliki ketrampilan mengajar. Untuk menjadikan guru sebagai tenaga professional maka perlu diadakan pembinaan secara terus menerus dan berkesinambungan, dan menjadikan guru sebagai tenaga kerja perlu diperhatikan, dihargai dan diakui keprofesionalannya. Untuk membuat mereka menjadi professional tidak sematamata hanya meningkatkan kompetensinya baik melalui pemberian penataran, pelatihan maupun memperoleh kesempatan untuk belajar lagi namun perlu juga memperhatikan guru dari segi yang lain seperti peningkatan disiplin, pemberian motivasi, pemberian bimbingan melalui supervisi.

Kinerja guru atau prestasi kerja adalah suatu hasil kerja yang dicapai seseorang dalam melaksanakan tugas-tugas yang dibebankan kepadanya yang didasarkan atas kecakapan, pengalaman, dan kesungguhan serta waktu (Hasibuan, 2001:94). Kinerja guru akan baik jika guru telah melakukan unsur-unsur yang terdiri dari kesetiaan dan komitmen yang tinggi pada tugas mengajar, menguasai dan mengembangkan bahan pelajaran, kedisiplinan dalam mengajar dan tugas lainnya, kreativitas dalam pelaksanaan pengajaran, kerjasama dengan semua warga sekolah, kepemimpinan yang menjadi panutan siswa, kepribadian yang baik, jujur dan objektif dalam membimbing siswa, serta tanggung jawab terhadap tugasnya. Oleh karena itu tugas kepala sekolah selaku manager adalah melakukan penilaian terhadap kinerja guru. Penilaian ini penting untuk dilakukan mengingat fungsinya sebagai alat motivasi bagi pimpinan kepada guru maupun bagi guru itu sendiri. Adapun penilaian tersebut melalui supervisi yang diberikan oleh kepala sekolah terhadap guru. Supervisi dalam hal ini adalah dalam upaya meningkatkan kinerja guru untuk mengaktifkan pembelajaran dan bimbingan yang diberikan oleh kepala sekolah yang nantinya berdampak kepada kinerja guru yaitu kualitas pengajaran.

Supervisi pendidikan didefinisikan sebagai proses pemberian layanan bantuan profesional kepada guru untuk meningkatkan kemampuannya dalam melaksanakan tugas-tugas pengelolaan proses pembelajaran secara efektif dan efisien (Bafadal, 2004:46). Dengan adanya pelaksanaan supervisi oleh kepala sekolah diharapkan memberi dampak terhadap terbentuknya sikap professional guru. Sikap profesional guru merupakan hal yang amat penting dalam memelihara dan meningkatkan profesionalitas guru, karena selalu berpengaruh pada perilaku dan aktivitas keseharian guru. Untuk itu diperlukan peran kepala sekolah untuk memotivasi para guru untuk meningkatkan kinerjanya dan tujuan supervisi untuk membantu guru-guru melihat dengan jelas tujuan pendidikan dan berusaha 
SEUNEUBOK LADA

Jurnal Ilmu-Ilmu Sejarah, Sosial, Budaya dan Kependidikan, 7 (1), 2020: 66-79

ISSN : 2356-0770

e-ISSN : 2685-2705

mencapai tujuan pendidikan itu dengan membina dan mengembangkan metodemetode dan prosedur pengajaran yang lebih baik.

Gambaran seperti pada kondisi di atas yang sekarang terjadi pada SMP Negeri 4 Birem Bayeun Kabupaten Aceh Timur. Dimana para guru sangat rendah kinerjanya dalam melaksanakan tugas. Adapun judul yang diangkat dalam artikel ini adalah "Peningkatan Kinerja Guru Terhadap Efektifitas Pembelajaran Melalui Supervisi Klinis di Sekolah Menengah Pertama”. Dengan demikian semoga dengan dilakukannya penelitian ini dapat merubah kinerja guru kearah yang lebih maju lagi, sehingga berpengaruh pada keberhasilan proses belajar mengajar ke arah yang lebih baik dan berdampak pada mutu pendidikan sekolah.

\section{B. TINJAUAN PUSTAKA \\ 1. Supervisi Kepala Sekolah \\ a. Pengertian}

Supervisi adalah strategi manajemen yang terdiri atas serangkaian kegiatan untuk memastikan bahwa mutu yang diharapkan dalam proses perencanaan, pelaksanaan kegiatan, dan evaluasi memenuhi standar yang telah ditentukan efektif (Purwanto, 2003: 32).

Sedangkan Sahertian (2000: 17) menyatakan bahwa supervisi adalah aktivitas menentukan kondisi/syarat-syarat yang essensial yang akan menjamin tercapainya tujuan-tujuan pendidikan. Dari definisi tersebut maka tugas kepala sekolah sebagai supervisor berarti bahwa dia hendaknya pandai meneliti, mencari, dan menentukan syarat-syarat mana sajakah yang diperlukan bagi kemajuan sekolahnya sehingga tujuan-tujuan pendidikan di sekolah itu semaksimal mungkin dapat tercapai.

Dengan demikian dapat disimpulkan bahwa supervisi kepala sekolah merupakan upaya seorang kepala sekolah dalam pembinaan guru agar guru dapat meningkatkan kualitas mengajarnya dengan melalui stategi manajemen atas serangkaian kegiatan atau langkah-langkah perencanaan, penampilan mengajar yang nyata serta mengadakan perubahan dengan cara yang rasional dalam usaha meningkatkan hasil belajar siswa.

\section{b. Faktor yang Mempengaruhi Keberhasilan Supervisi}

Menurut Purwanto (2004:118) ada beberapa faktor yang mempengaruhi berhasil tidaknya supervisi atau cepat-lambatnya hasil supervisi antara lain:

1) Lingkungan masyarakat tempat sekolah itu berada. Apakah sekolah itu di kota besar, di kota kecil, atau pelosok. Dilingkungan masyarakat orangorang kaya atau dilingkungan orang-orang yang pada umumnya kurang mampu. Dilingkungan masyarakat intelek, pedagang, atau petani dan lainlain.

2) Besar-kecilnya sekolah yang menjadi tanggung jawab kepala sekolah. Apakah sekolah itu merupakan kompleks sekolah yang besar, banyak 
SEUNEUBOK LADA

Jurnal Ilmu-Ilmu Sejarah, Sosial, Budaya dan Kependidikan, 7 (1), 2020: 66-79

ISSN : 2356-0770

e-ISSN : 2685-2705

jumlah guru dan siswanya, memiliki halaman dan tanah yang luas, atau sebaliknya.

3) Tingkatan dan jenis sekolah. Apakah sekolah yang di pimpin itu SD atau sekolah lanjutan, SLTP, SMU atau SMK dan sebagainya semuanya memerlukan sikap dan sifat supervisi tertentu.

4) Keadaan guru-guru dan pegawai yang tersedia. Apakah guru-guru di sekolah itu pada umumnya sudah berwenang, bagaimana kehidupan sosialekonomi, hasrat kemampuannya, dan sebagainya.

5) Kecakapan dan keahlian kepala sekolah itu sendiri. Di antara faktor-faktor yang lain, yang terakhir ini adalah yang terpenting. Bagaimanapun baiknya situasi dan kondisi yang tersedia, jika kepala sekolah itu sendiri tidak mempunyai kecakapan dan keahlian yang diperlukan, semuanya itu tidak akan ada artinya.

\section{c. Teknik-Teknik Supervisi}

Menurut Purwanto (2004:120-122), secara garis besar cara atau tehnik supervisi dapat digolongkan menjadi dua, yaitu tehnik perseorangan dan teknik kelompok.

1) Teknik perseorangan

Yang dimaksud dengan teknik perseorangan ialah supervisi yang dilakukan secara perseorangan. Beberapa kegiatan yang dapat dilakukan antara lain:

a) Mengadakan kunjungan kelas (classroom visiting)

Yang dimaksud dengan kunjungan kelas ialah kunjungan sewaktuwaktu yang dilakukan oleh seorang supervisor (kepala sekolah) untuk melihat atau mengamati seorang guru yang sedang mengajar. Tujuannya untuk mengobservasi bagaimana guru mengajar, apakah sudah memenuhi syarat-syarat didaktis atau metodik yang sesuai.

b) Mengadakan kunjungan observasi (observation visiting)

Guru-guru dari suatu sekolah sengaja ditugaskan untuk melihat/ mengamati seorang guru yang sedang mendemonstrasikan cara-cara mengajar suatu mata pelajaran tertentu. Misalnya cara menggunakan alat atau media yang baru, seperti audio-visual aids, cara mengajar dengan metode tertentu, seperti misalnya sosiodrama, problem solving, diskusi panel, fish bowl, metode penemuan (discovery), dan sebagainya.

c) Membimbing guru-guru tentang cara-cara mempelajari pribadi siswa dan atau mengatasi problem yang dialami siswa.

d) Membimbing guru-guru dalam hal-hal yang berhubungan dengan pelaksanaan kurikulum sekolah

2) Teknik kelompok

Merupakan supervisi yang dilakukan secara kelompok. Beberapa kegiatan yang dapat dilakukan antara lain:

a) Mengadakan pertemuan atau rapat (meetings)

Seorang kepala sekolah yang baik umumnya menjalankan tugasnya berdasarkan rencana yang telah disusunnya. Termasuk didalam perencanaan itu antara lain mengadakan rapat-rapat secara periodik dengan guru-guru. 
SEUNEUBOK LADA

Jurnal Ilmu-Ilmu Sejarah, Sosial, Budaya dan Kependidikan, 7 (1), 2020: 66-79

ISSN : 2356-0770

e-ISSN : 2685-2705

b) Mengadakan diskusi kelompok (group discussions)

Diskusi kelompok dapat diadakan dengan membentuk kelompokkelompok guru mata pelajaran sejenis. Kelompok-kelompok yang telah terbentuk itu diprogramkan untuk mengadakan pertemuan/diskusi guna membicarakan hal-hal yang berhubungan dengan usaha pengembangan dan peranan proses belajar-mengajar.

c) Mengadakan penataran-penataran (inservice-training)

Teknik supervisi kelompok yang dilakukan melalui penataran-penataran sudah banyak dilakukan. Misalnya penataran untuk guru-guru mata pelajaran tertentu, penataran tentang metodologi pengajaran, dan penataran tentang administrasi pendidikan. Mengingat bahwa penataran-penataran tersebut pada umumnya diselenggarakan oleh pusat atau wilayah, maka tugas kepala sekolah terutama adalah mengelola dan membimbing pelaksanaan tindak lanjut (follow-up) dari hasil penataran, agar dapat dipraktekkan oleh guru-guru.

\section{Kinerja Guru}

\section{a. Pengertian}

Menurut Djamarah (2005: 50) kinerja berarti sesuatu yang dicapai, prestasi diperlihatkan atau kemampuan kerja. Kinerja merupakan terjemahan bebas dari istilah performance yang artinya adalah prestasi kerja atau pelaksanaan kerja atau pencapaian kerja atau hasil kerja.

Anwar (2006: 22) memberikan pengertian kinerja sebagai seperangkat perilaku nyata yang ditunjukkan oleh seorang guru pada waktu memberikan pelajaran kepada siswanya. Kinerja guru dapat dilihat saat dia melaksanakan interaksi belajar-mengajar dikelas termasuk persiapannya baik dalam bentuk program semester maupun persiapan mengajar.

Kesimpulan yang dapat diambil dari pendapat dan teori kinerja guru diatas, bahwa kinerja guru adalah persiapan, pelaksanaan, dan pencapaian guru dalam melaksanakan interaksi belajar mengajar dikelas.

\section{b. Faktor-faktor yang Mempengaruhi Kinerja}

Banyak faktor yang mempengaruhi kinerja seseorang, baik yang berasal dari dalam diri maupun yang berasal dari luar. Mulyasa (2004: 79) menyatakan ada 3 (tiga) macam faktor yang dapat mempengaruhi kinerja seseorang yaitu:

1) Faktor Individual

Yaitu faktor-faktor yang meliputi sikap, sifat-sifat kepribadian, sifat fisik, keinginan atau motivasinya, umur, jenis kelamin, pendidikan,pengalaman kerja, latar belakang budaya dan variabel-variabel personal lainnya.

2) Faktor Situasional

Faktor sosial dan organisasi, meliputi : kebijaksanaan organisasi, jenis latihan dan pengawasan, sistem upah dan lingkungan sosial.

3) Faktor fisik dan pekerjaan, meliputi : metode kerja, desain dan kondisi alat-alat kerja, penataan ruang kerja dan lingkungan kerja (seperti penyinaran, kebisingan dan fentilasi). 
SEUNEUBOK LADA

Jurnal Ilmu-Ilmu Sejarah, Sosial, Budaya dan Kependidikan, 7 (1), 2020: 66-79

ISSN : 2356-0770

e-ISSN : 2685-2705

\section{c. Penilaian Kinerja}

Tugas manajer (Kepala Sekolah) terhadap guru salah satunya adalah melakukan penilaian atas kinerjanya. Penilaian ini mutlak dilaksanakan untuk mengetahui kinerja yang telah dicapai oleh guru. Apakah kinerja yang dicapai setiap guru baik, sedang, atau kurang. Penilaian ini penting bagi setiap guru dan berguna bagi sekolah dalam menetapkan kegiatannya.

Penilaian kinerja menurut Simamora (2007:415) adalah alat yang berfaedah tidak hanya untuk mengevaluasi kerja dari para karyawan, tetapi juga untuk mengembangkan dan memotivasi kalangan karyawan. Sejalan dengan Pendapat Hasibuan (2000:87) penilaian prestasi adalah kegiatan manajer untuk mengevaluasi prestasi kerja karyawan serta menetapkan kebijaksanaan selanjutnya.

Sehubungan dengan hal diatas maka penilaian kinerja guru berdasarkan Standar Kompetensi Guru. Moedjiono (2006: 56) menyatakan bahwa standar kompetensi guru dapat diartikan sebagai "suatu ukuran yang ditetapkan atau dipersyaratkan". Lebih lanjut dinyatakan bahwa Standar Kompetensi Guru adalah suatu ukuran yang ditetapkan atau dipersyaratkan dalam bentuk penguasaan pengetahuan dan perilaku perbuatan bagi seorang guru agar berkelayakan untuk menduduki jabatan fungsional sesuai dengan bidang tugas, kualifikasi dan jenjang pendidikan. Berdasarkan pengertian tersebut, standar kompetensi guru dibagi dalam tiga komponen yang saling mengait, yakni: 1.) pengelolaan pembelajaran, 2.) pengembangan profesi, dan 3.) penguasaan akademik. Ketiga komponen SKG tersebut, masing-masing terdiri atas beberapa kompetensi, komponen pertama terdiri atas empat kompetensi, komponen kedua memiliki satu kompetensi, dan komponen ketiga terdiri atas dua kompetensi.

\section{PEMBAHASAN}

Berdasarkan hasil penelitian yang telah dilakukan bahwa Supervisi Klinis dapat meningkatkan kompetensi guru dalam kinerja guru terhadap efektifitas pembelajaran di SMP Negeri 4 Birem Bayeun, Kec. Birem Bayeun, Kab. Aceh Timur. Hal tersebut dapat dianalisis dan dibahas sebagai berikut:

\section{Pembahasan Hasil Supervisi Kondisi Awal}

Sebelum dilaksanakan penelitian yaitu pada kondisi awal kinerja guru sangat rendah. Hal ini tentu saja sangat berpengaruh pada efektifitas proses pembelajaran dan dapat menyebabkan mutu pendidikan menjadi rendah. Untuk itulah peneliti berpikir keras mencari solusi bagaimana mengatasi permasalahan tersebut. Kinerja guru pada kondisi awal sebelum dilaksanakan penelitian sangatlah rendah, hasil pengamatan yang didapat berdasarkan kenyataan di lapangan. Dari 20 orang jumlah guru, hampir semuanya menunjukkan kinerja yang rendah, hal ini disebabkan para guru kurang memiliki inisiatif dan kesadaran 
dalam meningkatkan profesionalismenya sebagai seorang pendidik sehingga pembelajaran tidak efektif.

Berikut hasil pengamatan kinerja guru terhadap efektifitas pembelajaran pada kondisi awal yang di sajikan pada tebel di bawah ini.

Tabel 1 Hasil Pengamatan Terhadap Kinerja Guru Pada Kondisi Awal

\begin{tabular}{|l|l|c|c|c|c|c|c|c|c|}
\hline \multirow{2}{*}{ No } & \multicolumn{1}{|c|}{ Uraian } & \multicolumn{3}{|c|}{ Kriteria } & \multicolumn{4}{|c|}{ Persentase } \\
\cline { 2 - 9 } & A & B & C & D & A & B & C & D \\
\hline 1 & $\begin{array}{l}\text { Penguasaan Mata } \\
\text { Pelajaran }\end{array}$ & 4 & 10 & 6 & $0 \%$ & $20 \%$ & $50 \%$ & $30 \%$ \\
\hline 2 & $\begin{array}{l}\text { Menyusun Rencana } \\
\text { Pelaksanaan } \\
\text { Pembelajaran } \\
\text { (RPP) dengan baik. }\end{array}$ & 0 & 1 & 14 & 5 & $0 \%$ & $5 \%$ & $70 \%$ & $25 \%$ \\
\hline 3 & $\begin{array}{l}\text { Menguasai Kelas } \\
\text { Dalam Proses } \\
\text { Belajar Mengajar }\end{array}$ & 0 & 3 & 14 & 3 & $0 \%$ & $15 \%$ & $70 \%$ & $15 \%$ \\
\hline 4 & $\begin{array}{l}\text { Menguasai } \\
\text { Penggunaan Media } \\
\text { Pembelajaran }\end{array}$ & 0 & 3 & 9 & 8 & $0 \%$ & $15 \%$ & $45 \%$ & $40 \%$ \\
\hline 5 & $\begin{array}{l}\text { Kelengkapan } \\
\text { Administrasi Kelas }\end{array}$ & 1 & 2 & 9 & 8 & $5 \%$ & $10 \%$ & $45 \%$ & $40 \%$ \\
\hline
\end{tabular}

Setelah melakukan pengamatan pada kondisi awal, berdasarkan hasil pengamatan tersebut peneliti bersama observer mendiskusikan dan merumuskan usaha untuk melakukan perbaikan melalui penelitian tindakan sekolah dengan tujuan meningkatkan kinerja guru terhadap efektifitas pembelajaran.

\section{Pembahasan Hasil Supervisi Siklus I}

Pada pelaksanaan tindakan siklus I menunjukkan adanya sedikit peningkatan kinerja guru terhadap efektivitas pembelajaran. Berdasarkan pengamatan peneliti selama penelitian berlangsung dengan sasaran utama untuk melihat peningkatan kinerja guru, terhadap efektifitas pembelajaran yang dilaksanana oleh guru dapat dilihat pada tabel berikut:

Tabel 2. Kemampuan Guru Menguasai Materi Pelajaran Pada Siklus I

\begin{tabular}{|c|c|c|c|}
\hline No & Kriteria & Frekuensi & Persentase (\%) \\
\hline 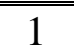 & A (amat baik) & 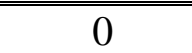 & 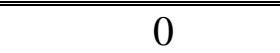 \\
\hline 2 & B (baik) & 7 & $35 \%$ \\
\hline 3 & C (cukup) & 8 & $40 \%$ \\
\hline 4 & D (kurang) & 5 & $25 \%$ \\
\hline & Jumlah & 20 & 100 \\
\hline
\end{tabular}


Data kemampuan guru dalam menguasai materi pelajaran di atas dapat diperjelas melalui grafik sebagai berikut;

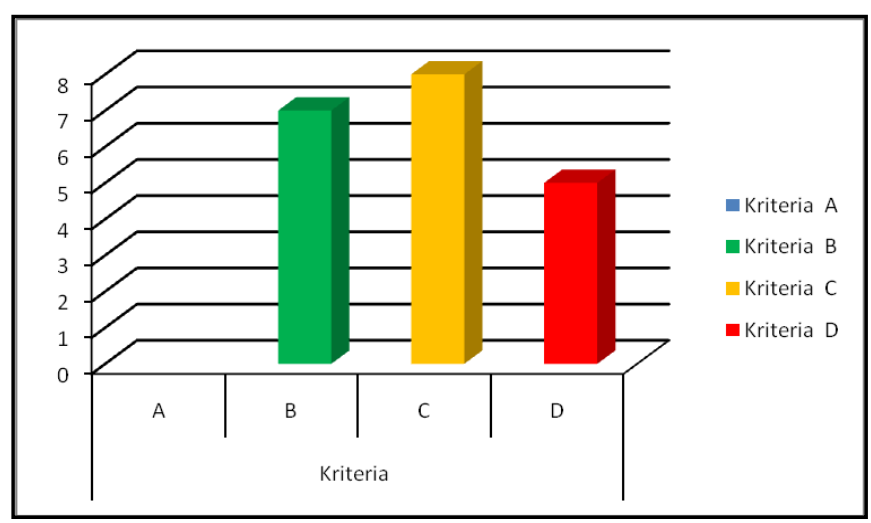

Gambar 1. Grafik Kemampuan Guru Menguasai Mata Pelajaran Siklus I

Dari paparan data melalui tabel dan grafik, diketahui bahwa pada Siklus I, kemampuan guru menguasai mata pelajaran yang mendapat kriteria B (baik) sebanyak 7 orang (35\%), kriteria C (cukup) 8 orang $(40 \%)$, dan kriteria D (kurang) 5 orang (25\%). Sedangkan yang mendapat kriteria A (amat baik) belum ada.

Sedangkan hasil pengamatan kemampuan guru dalam menyusun Rencana Pelaksanaan Pembelajaran (RPP) siklus I dengan baik tertera pada tabel berikut:

Tabel 3. Kemampuan Guru Menyusun RPP Siklus I

\begin{tabular}{|c|c|c|c|}
\hline No & Kriteria & Frekuensi & Persentase $(\%)$ \\
\hline 1 & A (amat baik) & 0 & 0 \\
\hline 2 & B (baik) & 3 & $15 \%$ \\
\hline 3 & C (cukup) & 15 & $75 \%$ \\
\hline 4 & D (kurang) & 2 & $10 \%$ \\
\hline & Jumlah & 20 & 100 \\
\hline
\end{tabular}

Data kemampuan guru dalam meyusun RPP dengan baik pada tabel di atas dapat diperjelas melalui grafik sebagai berikut;

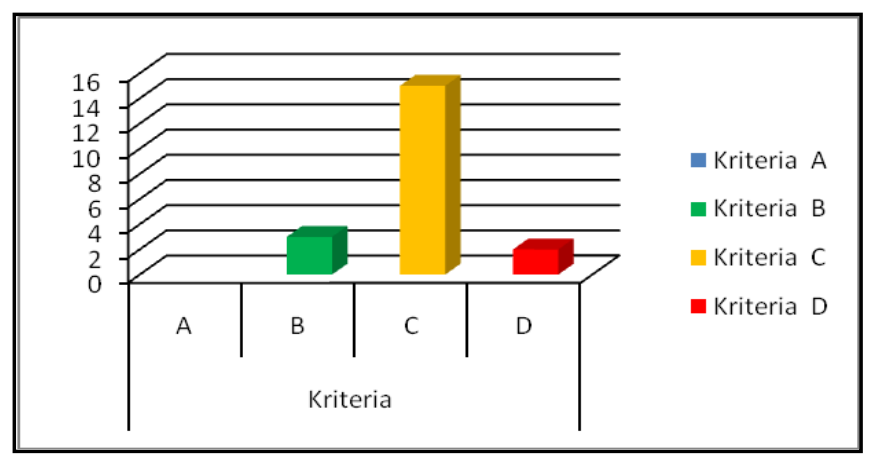

Gambar 2. Grafik Kemampuan Guru Menyusun RPP Siklus I 
SEUNEUBOK LADA

Jurnal Ilmu-Ilmu Sejarah, Sosial, Budaya dan Kependidikan, 7 (1), 2020: 66-79

ISSN : 2356-0770

e-ISSN : 2685-2705

Dari paparan data melalui tabel dan grafik, diketahui bahwa pada Siklus I, kemampuan guru dalam menyususn RPP yang mendapat kriteri B (baik) ada 3 orang (15\%), kriteria C (cukup) ada 15 orang (75 \%) dan kriteria D (kurang) sebanyak 2 orang (10\%). Sedangkan kriteria A (amat baik) belum ada.

Berikutnya hasil pengamatan untuk melihat kemampuan guru dalam penguasaan kelas saat proses pembelajaran pada siklus I tertera pada tabel berikut:

Tabel 4. Kemampuan Guru Dalam Penguasaan Kelas Siklus I

\begin{tabular}{|c|c|c|c|}
\hline No & Kriteria & Frekuensi & Persentase (\%) \\
\hline 1 & A (amat baik) & 2 & $10 \%$ \\
\hline 2 & B (baik) & 4 & $20 \%$ \\
\hline 3 & C (cukup) & 11 & $55 \%$ \\
\hline 4 & D (kurang) & 3 & $15 \%$ \\
\hline & Jumlah & 20 & 100 \\
\hline
\end{tabular}

Data kemampuan guru dalam penguasaan kelas pada tabel di atas dapat diperjelas melalui grafik sebagai berikut;

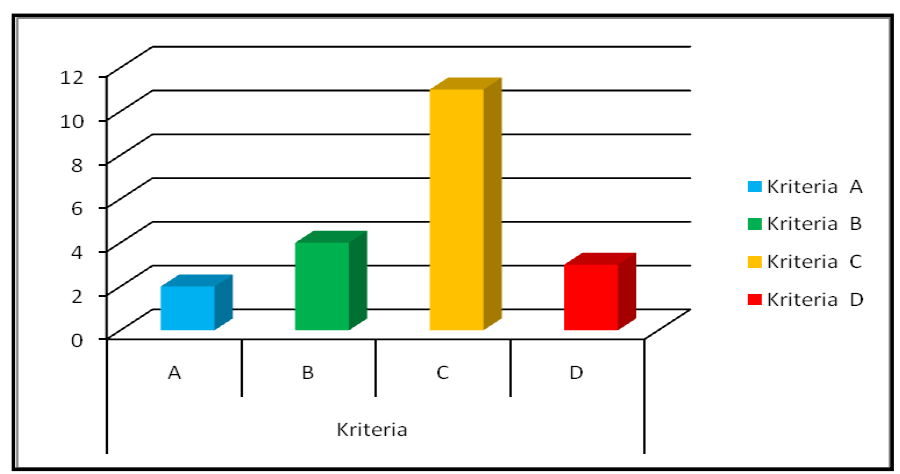

Gambar 3. Grafik Kemampuan Guru Dalam Penguasaan Kelas Siklus I

Dari paparan data melalui tabel dan grafik, diketahui bahwa pada Siklus I, kemampuan guru dalam penguasaan kelas yang mendapat kriteria A (amat baik) sebanyak 2 orang (10\%), kriteria B (baik) ada 4 orang (20\%), kriteria C (cukup) ada 11 orang (55\%), dan yang mendapat kriteria D (kurang) ada 3 orang (15\%).

Berikutnya hasil pengamatan untuk melihat kemampuan guru dalam penggunaan media dan sumber belajar, mengendalikan, serta membuat alat peraga sederhana pada siklus I tertera pada tabel berikut:

Tabel 5. Kemampuan Guru dalam penggunaan media dan sumber belajar, mengendalikan, serta membuat alat peraga sederhana pada siklus I

\begin{tabular}{|c|c|c|c|}
\hline No & Kriteria & Frekuensi & Persentase (\%) \\
\hline 1 & A (amat baik) & 1 & $5 \%$ \\
\hline 2 & B (baik) & 2 & $10 \%$ \\
\hline 3 & C (cukup) & 13 & $65 \%$ \\
\hline 4 & D (kurang) & 4 & $20 \%$ \\
\hline & Jumlah & 20 & 100 \\
\hline
\end{tabular}


Data kemampuan guru pada tabel diatas dapat diperjelas melalui grafik sebagai berikut;

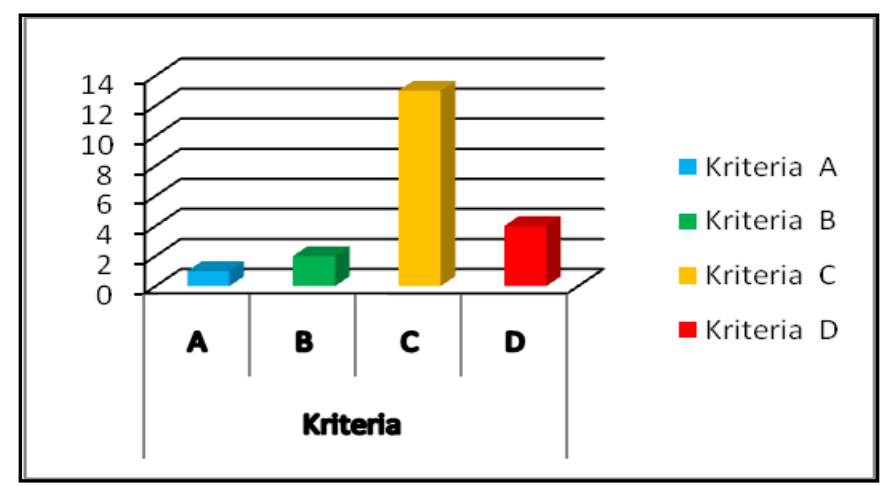

Gambar 4. Grafik Kemampuan Guru Dalam Penggunaan Media Dan Sumber

Belajar, Mengendalikan, Serta Membuat Alat Peraga Sederhana Siklus I

Dari paparan data melalui tabel dan grafik, diketahui bahwa pada Siklus I, kemampuan guru dalam penggunaan media dan sumber belajar, mengendalikan, serta membuat alat peraga sederhana yang mendapat kriteria A (amat baik) ada 1 orang (5\%), kriteria B (baik) ada 2 orang (10\%), kriteria C (cukup) ada 13 orang (65\%), dan kriteria D (kurang) ada 4 orang (20\%).

Berikutnya hasil pengamatan untuk melihat kemampuan guru dalam melengkapi administrasi kelas pada siklus I tertera pada tabel berikut:

Tabel 6. Kemampuan Guru dalam Melengkapi Administrasi Kelas Siklus I

\begin{tabular}{|c|c|c|c|}
\hline No & Kriteria & Frekuensi & Persentase (\%) \\
\hline 1 & A (amat baik) & 3 & $15 \%$ \\
\hline 2 & B (baik) & 4 & $20 \%$ \\
\hline 3 & C (cukup) & 10 & $50 \%$ \\
\hline 4 & D (kurang) & 3 & $15 \%$ \\
\hline & Jumlah & 20 & 100 \\
\hline
\end{tabular}

Data kemampuan guru dalam melengkapi administrasi kelas pada tabel diatas dapat diperjelas melalui grafik sebagai berikut;

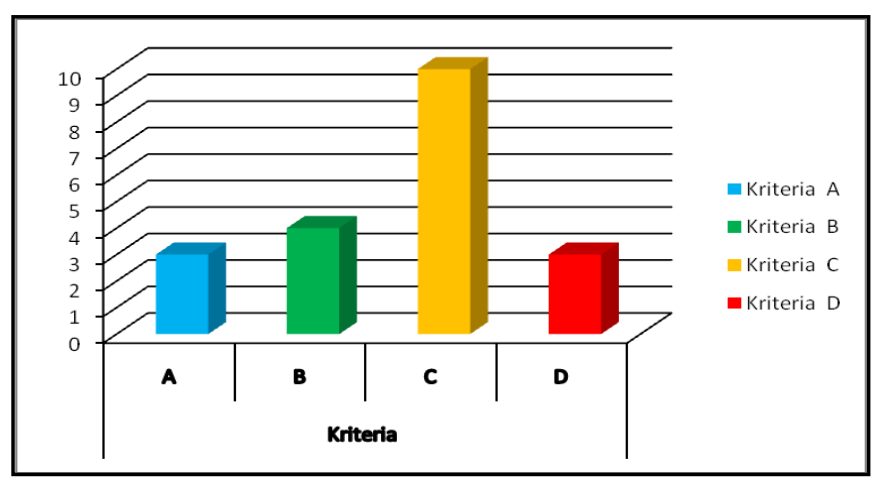


SEUNEUBOK LADA

Jurnal Ilmu-Ilmu Sejarah, Sosial, Budaya dan Kependidikan, 7 (1), 2020: 66-79

ISSN : 2356-0770

e-ISSN : 2685-2705

Gambar 5. Grafik Kemampuan Guru Melengkapi Administrasi Kelas Siklus I

Dari paparan data melalui tabel dan grafik, diketahui bahwa pada Siklus I, kemampuan guru dalam Melengkapi Administrasi Kelas yang mendapat kriteria A (amat baik) ada 3 orang (15\%), kriteria B (baik) ada 4 orang (20\%), kriteria C (cukup) ada 10 orang (50\%) dan kriteria D (kurang) ada 3 orang (15\%).

Berdasarkan hasil yang dicapai pada pelaksanaan tindakan siklus I tersebut, peneliti merasa belum puas atas pencapaian tersebut. Oleh karena itu peneliti melanjutkan pada siklus II dengan terlebih dahulu melakukan perbaikan atas kelemahan yang terjadi pada siklus sebelumnya.

\section{Pembahasan Hasil Supervisi Siklus II}

Pada pelaksanaan tindakan siklus II terjadi peningkatan yang cukup signifikan. Hal ini disebakan peneliti secara terus menerus melakukan bimbingan dan arahan kepada para guru agar memiliki kesadaran diri dan tanggung jawab sebagai pendidik untuk meningkatkan kinerja sehingga proses pembelajaran menjadi lebih efektif yang pada akhirnya akan meningkatkan mutu pendidikan. Berdasarkan pengamatan peneliti selama penelitian berlangsung dengan sasaran utama untuk melihat peningkatan kinerja guru, terhadap efektifitas pembelajaran yang dilaksanana oleh guru dapat dilihat pada tabel berikut:

Tabel 7. Kemampuan Guru Menguasai Materi Pelajaran pada Siklus II

\begin{tabular}{|c|c|c|c|}
\hline No & Kriteria & Frekuensi & Persentase $(\%)$ \\
\hline 1 & A (amat baik) & 8 & $40 \%$ \\
\hline 2 & B (baik) & 9 & $45 \%$ \\
\hline 3 & C (cukup) & 3 & $15 \%$ \\
\hline 4 & D (kurang) & 0 & $0 \%$ \\
\hline & Jumlah & 20 & 100 \\
\hline
\end{tabular}

Data kemampuan guru dalam menguasai materi pelajaran di atas dapat diperjelas melalui grafik sebagai berikut;

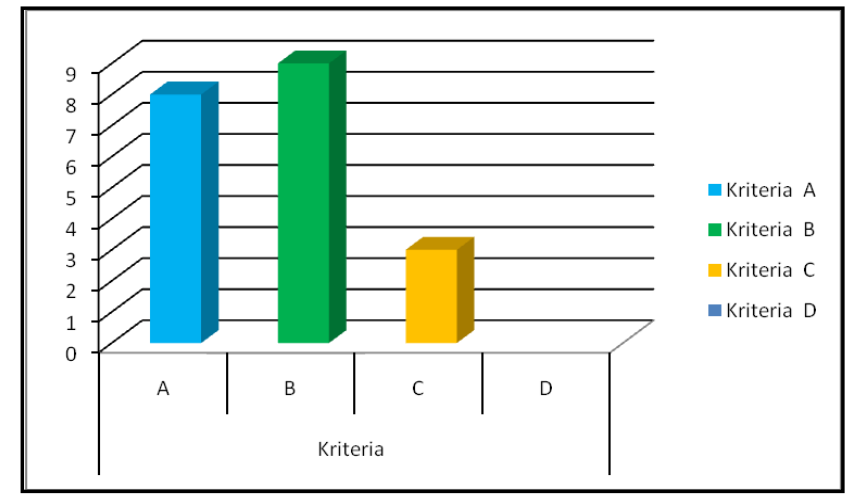

Gambar 6. Grafik Kemampuan Guru Menguasai Mata Pelajaran Siklus II 
SEUNEUBOK LADA

Jurnal Ilmu-Ilmu Sejarah, Sosial, Budaya dan Kependidikan, 7 (1), 2020: 66-79

ISSN : 2356-0770

e-ISSN : 2685-2705

Dari paparan data melalui tabel dan grafik, diketahui bahwa pada Siklus II, kemampuan guru menguasai mata pelajaran yang mendapat kriteria A (amat baik) ada 8 orang ( $40 \%$ ) kriteria B (baik) sebanyak 9 orang (45\%), kriteria C (cukup) 3 orang (15\%), Sedangkan yang mendapat kriteria D (kurang) dan sudah tidak ada lagi.

Berikutnya hasil pengamatan kemampuan guru dalam menyusun Rencana Pelaksanaan Pembelajaran (RPP) siklus II dengan baik tertera pada tabel berikut:

Tabel 8. Kemampuan Guru Menyusun RPP Siklus II

\begin{tabular}{|c|c|c|c|}
\hline \hline No & Kriteria & Frekuensi & Persentase (\%) \\
\hline \hline 1 & A (amat baik) & 5 & $25 \%$ \\
\hline 2 & B (baik) & 11 & $55 \%$ \\
\hline 3 & C (cukup) & 4 & $20 \%$ \\
\hline 4 & D (kurang) & 0 & $0 \%$ \\
\hline & Jumlah & $\mathbf{2 0}$ & $\mathbf{1 0 0}$ \\
\hline \hline
\end{tabular}

Data kemampuan guru dalam meyusun RPP dengan baik pada tabel di atas dapat diperjelas melalui grafik sebagai berikut;

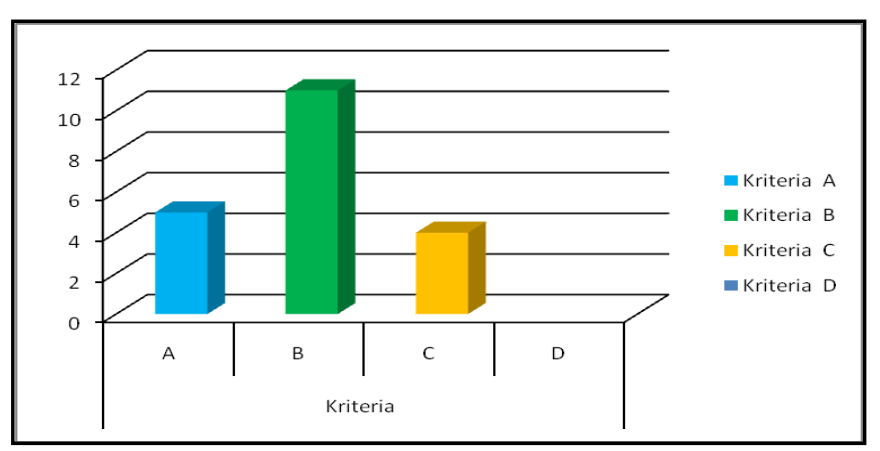

Gambar 7. Grafik Kemampuan Guru Menyusun RPP Siklus II

Dari paparan data melalui tabel dan grafik, diketahui bahwa pada Siklus II, kemampuan guru dalam menyususn RPP yang mendapat kriteri A (amat baik) ada 5 orang ( $25 \%$ ), kriteria B (baik) ada 11 orang (55\%), kriteria C (cukup) ada 4 orang $(20 \%)$ Sedangkan kriteria D (kurang) sudah tidak ada lagi.

Berikutnya hasil pengamatan kemampuan guru dalam penguasaan kelas saat proses pembelajaran pada siklus II tertera pada tabel berikut:

Tabel 9. Kemampuan Guru dalam Penguasaan Kelas Siklus II

\begin{tabular}{|c|c|c|c|}
\hline No & Kriteria & Frekuensi & Persentase (\%) \\
\hline 1 & A (amat baik) & 3 & $15 \%$ \\
\hline 2 & B (baik) & 16 & $80 \%$ \\
\hline 3 & C (cukup) & 1 & $5 \%$ \\
\hline 4 & D (kurang) & 0 & $0 \%$ \\
\hline & Jumlah & 20 & 100 \\
\hline
\end{tabular}


Data kemampuan guru dalam penguasaan kelas pada tabel di atas dapat diperjelas melalui grafik sebagai berikut;

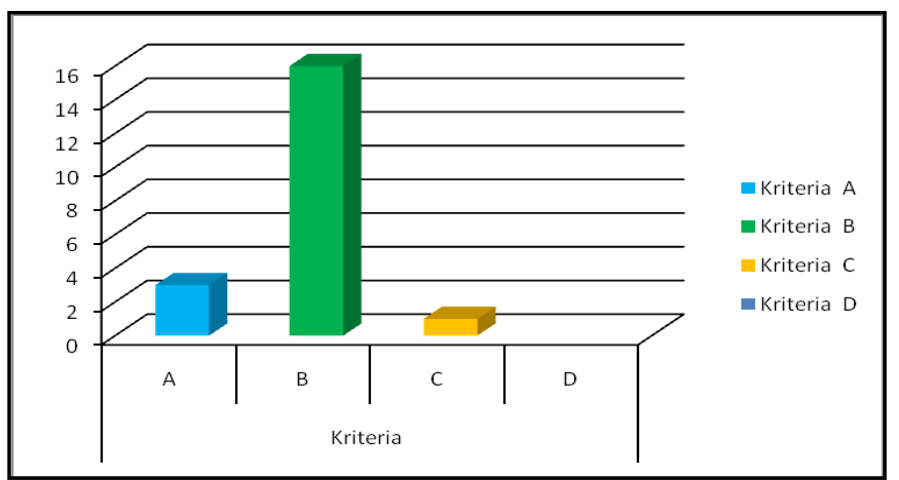

Gambar 8. Grafik Kemampuan Guru dalam Penguasaan Kelas Siklus II

Dari paparan data melalui tabel dan grafik, diketahui bahwa pada Siklus II, kemampuan guru dalam penguasaan kelas yang mendapat kriteria A (amat baik) sebanyak 3 orang (15\%), kriteria B (baik) ada 16 orang (80\%), kriteria C (cukup) ada 1 orang $(5 \%)$, dan yang mendapat kriteria D (kurang ) tidak ada.

Berikutnya hasil pengamatan kemampuan guru dalam penggunaan media dan sumber belajar, mengendalikan, serta membuat alat peraga sederhana pada siklus II tertera pada tabel berikut:

Tabel 10. Kemampuan Guru dalam penggunaan media dan sumber belajar, mengendalikan, serta membuat alat peraga sederhana pada siklus II

\begin{tabular}{|c|c|c|c|}
\hline No & Kriteria & Frekuensi & Persentase $(\%)$ \\
\hline 1 & A (amat baik) & 6 & $30 \%$ \\
\hline 2 & B (baik) & 7 & $35 \%$ \\
\hline 3 & C (cukup) & 7 & $35 \%$ \\
\hline 4 & D (kurang) & 0 & $0 \%$ \\
\hline & Jumlah & 20 & 100 \\
\hline
\end{tabular}

Data kemampuan guru dalam penggunaan media dan sumber belajar, mengendalikan, serta membuat alat peraga sederhana pada tabel diatas dapat diperjelas melalui grafik sebagai berikut;

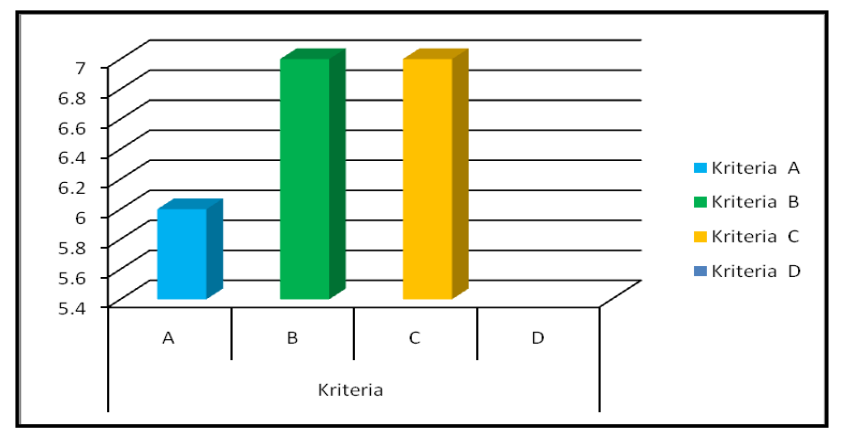

Gambar 9. Grafik kemampuan guru dalam penggunaan media dan sumber belajar, mengendalikan, serta membuat alat peraga sederhana siklus II 
Dari paparan data melalui tabel dan grafik, diketahui bahwa pada Siklus II, kemampuan guru dalam penggunaan media dan sumber belajar, mengendalikan, serta membuat alat peraga sederhana yang mendapat kriteria A (amat baik) ada 6 orang (30\%), kriteria B (baik) ada 7 orang (35\%), kriteria C (cukup) ada 7 orang (35\%), dan kriteria D (kurang) tidak ada lagi.

Berikutnya hasil pengamatan untuk melihat kemampuan guru dalam melengkapi administrasi kelas pada siklus II tertera pada tabel berikut:

Tabel 11. Kemampuan Guru dalam Melengkapi Administrasi Kelas Siklus II

\begin{tabular}{|c|c|c|c|}
\hline No & Kriteria & Frekuensi & Persentase (\%) \\
\hline 1 & A (amat baik) & 13 & $65 \%$ \\
\hline 2 & B (baik) & 5 & $25 \%$ \\
\hline 3 & C (cukup) & 2 & $10 \%$ \\
\hline 4 & D (kurang) & 0 & $0 \%$ \\
\hline & Jumlah & 20 & 100 \\
\hline
\end{tabular}

Data kemampuan guru dalam melengkapi administrasi kelas pada tabel diatas dapat diperjelas melalui grafik sebagai berikut;

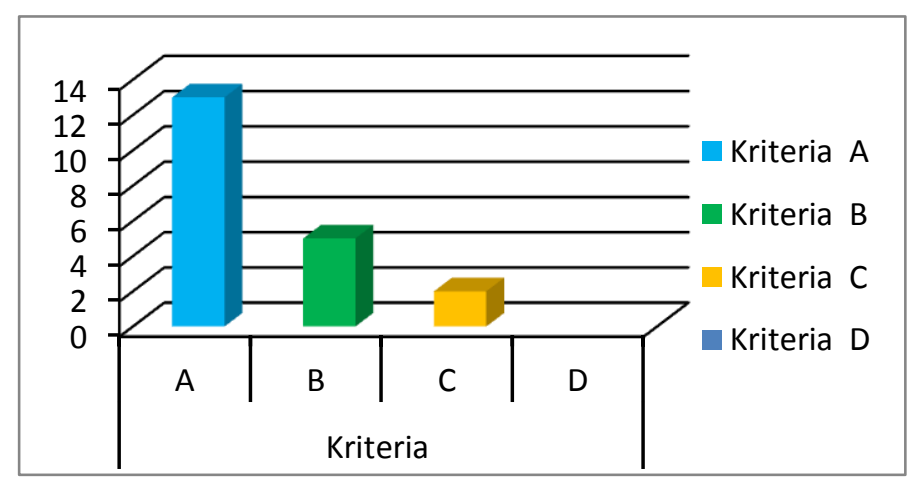

Gambar 10. Grafik kemampuan guru melengkapi administrasi kelas siklus II

Dari paparan data melalui tabel dan grafik, diketahui bahwa pada Siklus II, kemampuan Guru dalam Melengkapi Administrasi Kelas yang mendapat kriteria A (amat baik) ada 13 orang (65\%), kriteria B (baik) ada 5 orang (25\%), kriteria $\mathrm{C}$ (cukup) ada 2 orang (10\%) dan kriteria D (kurang) tidak ada.

Berdasarkan hasil yang dicapai pada pelaksanaan tindakan siklus II tersebut, peneliti merasa puas atas keberhasilan tersebut. Oleh karena itu peneliti menghentikannya pada siklus II karena sudah dianggap berhasil.

\section{KESIMPULAN}

Berdasarkan analisis data dari hasil tindakan siklus I dan II dapat disimpulkan bahwa, supervisi kepala sekolah sangat berpengaruh sebagai upaya 
SEUNEUBOK LADA

Jurnal Ilmu-Ilmu Sejarah, Sosial, Budaya dan Kependidikan, 7 (1), 2020: 66-79

ISSN : 2356-0770

e-ISSN : 2685-2705

meningkatkan kinerja guru terhadap efektifitas pembelajaran. Hal ini dibuktikan dengan adanya peningkatan kinerja guru pada setiap siklusnya.

Dari 20 orang jumlah guru pada SMP Negeri 4 Birem Bayeun, setelah dilaksanakan tindakan pada siklus II hampir semuanya telah memiliki kesadaran untuk meningkatkan kinerjanya. Hal ini akan berdampak pada peningkatan mutu pendidikan di sekolah.

\section{DAFTAR PUSTAKA}

Anwar, 2006. Psikologi Kerja. Jakarta :Rineka Cipta

Bafadal, 2004 Pemikiran tentang Supervisi Pendidikan. Jakarta: Bumi Aksara

Djamarah. 2005. Manajemen Personalia dan Sumber Daya Manusia. Yogyakarta: BPFE.

Hasibuan, 2005. Guru Dalam Proses Belajar Mengajar. Bandung: PT. Sinar Baru Algensindo

Moedjiono, 2006. Menejemen Tenaga Pendidik Yang Profesional. Yogyakarta: Liberty

Mulyasa, E. 2004. Menjadi Kepala Sekolah Profesional. Bandung: Remaja Rosdakarya

Purwanto, M. Ngalim. 2004. Administrasi dan Supervisi Pendidikan. Bandung: Remaja Rosdakarya

Sahertian, 2000. Organisasi dan Motivasi. Jakarta : Bumi Aksara

Simamora, 2007. Manajemen Sumber Daya Manusia. Jakarta : Bumi Aksara. 